\title{
PENDEKATAN STATISTIK MULTIVARIAT TERHADAP DATA GEOKIMIA TANAH MULTI- UNSUR UNTUK MENGIDENTIFIKASI MINERALISASI Au-Cu EPITERMAL SULFIDA TINGGI DI DAERAH PROSPEK "X", KECAMATAN BATANG ASAI, KABUPATEN SAROLANGUN, PROVINSI JAMBI
}

\section{MULTIVARIATE STATISTICAL APPROACH OF MULTI-ELEMENT SOIL GEOCHEMICAL DATA FOR IDENTIFYING THE HIGH SULFIDATION EPITHERMAL AU-Cu MINERALIZATION AT "X" PROSPECT, BATANG ASAI, SAROLANGUN DISTRICT, JAMBI PROVINCE}

\author{
Fiandri I. Rinawan ${ }^{1}$, Mega F. Rosana1, Bronto Sutopo ${ }^{2}$ dan Euis T. Yuningsih ${ }^{1}$ \\ ${ }^{1}$ Fakultas Teknik Geologi, Universitas Padjadjaran, Jatinangor, Sumedang, 45363 \\ ${ }^{2}$ PT ANTAM Tbk Unit Geomin, JI. Letjen TB Simatupang No. 1, Lingkar Selatan, \\ Tanjung Barat, Jakarta, 12530 \\ fiandriir_geounpad07@yahoo.com
}

\begin{abstract}
ABSTRAK
Analisis statistik multivariat dilakukan terhadap data analisis kimia multi-unsur conto tanah menutupi endapan mineral yang menempati litologi batuan vulkanik Formasi Hulu Simpang berumur Oligosen Akhir - Awal Miosen, terletak di daerah Prospek "X", Kabupaten Sarolangun, Jambi. Tujuan penelitian ini adalah untuk mengetahui hubungan antara Au dan $\mathrm{Cu}$ dengan unsur-unsur lain agar dapat teridentifikasi kemungkinan mineralisasi $\mathrm{Au}-\mathrm{Cu}$ endapan sulfida tinggi dari data geokimia tanah. Penelitian ini difokuskan pada 12 unsur terdiri $\mathrm{Au}, \mathrm{Ag}, \mathrm{Hg}$, Te, Sb, As, Bi, Cu, Pb, Zn, Sn, dan Mo. Hasil analisis kimia 376 conto tanah kisi dari daerah penelitian dengan luas berkisar $5,3 \mathrm{~km}^{2}$ disajikan dengan menggunakan statistik multivariat yang terdiri analisis korelasi dan analisis klaster hirarki. Kedua metode statistik multivariat tersebut mengindikasikan kompilasi hasil analisis yang bersifat representatif yaitu Klaster I Cu-As-Sb-Te dengan nilai korelasi berkisar 0.50-0.93 dan Klaster II Au-Bi dengan nilai korelasi 0.26; adapun yang bersifat tidak representatif yaitu Klaster III Pb-Mo-Zn dengan nilai korelasi berkisar 0.09-0.10 dan Klaster IV Sn-Hg-Ag dengan nilai korelasi berkisar 0.02-0.25. Klaster I dan II berkaitan dengan kumpulan asosiasi unsur indikasi mineralisasi Au-Cu epitermal sulfida tinggi. Daerah mineralisasi ini tersusun oleh ubahan argilik lanjut dari breksi vulkanik, tuf, andesit, dan dasit; serta dicirikan oleh kehadiran mineral bijih enargit, luzonit, kalkopirit, arsenopirit, dan kovelit.
\end{abstract}

Kata kunci: Analisis Multivariat, Multi-Unsur, Geokimia Tanah, Epitermal Sulfida Tinggi, Sarolangun

\section{ABSTRACT}

Multivariate statistical analyses had been applied to the data of soil samples multi-elements covering mineral sediment in the volcanic rocks of the Late Oligocene to Early Miocene Hulusimpang Formation in the $X$ prospect area of Sarolangun Regency, Jambi Province. This paper aims to reveal the relationships between $\mathrm{Au}$ and $\mathrm{Cu}$ with other elements to identify the probability of high sulphide $\mathrm{Au}-\mathrm{Cu}$ mineralization from soil geochemistry data. This study focuses on 12 elements i.e. $\mathrm{Au}, \mathrm{Ag}, \mathrm{Hg}, \mathrm{Te}, \mathrm{Sb}, \mathrm{As}, \mathrm{Bi}, \mathrm{Cu}, \mathrm{Pb}, \mathrm{Zn}$, Sn and Mo. Result of chemical analysis from 376 soil samples of gridding pattern as large $5.3 \mathrm{~km} 2$ is presented multivariate analysis consists of correlation and hierarchy cluster analyses. Both of this method indicate the compilation of representative samples for Cluster I Cu-As-Sb-Te with correlation coefficient of $0.50-0.93$ and Cluster II Au-Bi with coefficient of 0.26 . The non-representative samples are for Cluster III Pb-Mo-Zn with coefficient of $0.09-0.10$ and Cluster IV Sn-Hg-Ag with coefficient of $0.02-0.25$. Cluster I and II is correlated with the 


\section{MAKALAH ILMIAH}

element association of high sulphide $\mathrm{Au}-\mathrm{Cu}$ mineralization. This mineralization zone is composed of advance argillic alteration from volcanic breccia, tuff, andesite and dacite, as well as characterized by the occurrence of ore minerals i.e. enargite, luzonite, chalcopyrite, arsenopyrite and covelite.

Keywords: Multivariate Analyses, Multi-Elements, Soil Geochemistry, High Sulphide Epithermal, Sarolangun

\section{PENDAHULUAN}

Daerah prospek "X" sebagai daerah penelitian, merupakan bagian dari IUP Eksplorasi PT ANTAM Tbk yang termasuk dalam kawasan Batang Asai, Kabupaten Sarolangun, Provinsi Jambi. Daerah ini ditempati satuan batuan vulkanik yang merupakan bagian dari busur vulkanik Pegunungan Barisan berumur Tersier, yang dipengaruhi oleh sesar mendatar Sumatra Fault System (SFS) berarah baratlaut-tenggara, dikenal sebagai Zona Sesar Semangko (Darman and Sidi, 2000). Zona sesar ini diinterpretasikan berkaitan dengan zona mineralisasi hidrotermal di daerah penelitian. Di daerah prospek tersebut, telah dilakukan eksplorasi oleh Unit Geomin (2014), diantaranya dilakukan pemetaan geologi, alterasi dan mineralisasi, geofisika, serta pengambilan conto geokimia tanah horison B. Berdasarkan hasil eksplorasi, terdapat indikasi endapan tipe epitermal sulfida tinggi.

Eksplorasi geokimia tanah, berkaitan erat dengan analisis kimia multi unsur diantaranya sebagai pathfinder, diterapkan untuk dapat menunjukkan unsur-unsur yang menjadi target sebagai blind deposits (Joyce, 1984). Unsur pathfinder yaitu unsur-unsur kimia tertentu berfungsi sebagai unsur penciri yang memiliki hubungan genetik/kekerabatan dengan unsur target sehingga dapat diterapkan dalam menentukan zona anomali sebagai indikasi potensi komoditi pada tipe endapan tertentu (Niton, 2012). Untuk dapat mengetahui hubungan antara unsur target dan unsur penciri, digunakan pendekatan statistik multi-unsur (McQueen, 2002).
Berkaitan dengan hal tersebut, dalam penelitian ini, metode statistik multivariat digunakan untuk mengevaluasi data geokimia tanah multi unsur. Metode statistik ini secara kuantitatif dapat memfasilitasi pemahaman tentang variasi suatu unsur dan hubungan antara unsur target dengan unsur-unsur yang lain. Metode ini berguna dalam penentuan kemungkinan unsur-unsur yang saling memiliki kekerabatan, khususnya Au dan $\mathrm{Cu}$ sebagai unsur target yang mengindikasikan mineralisasi epitermal sulfida tinggi.

\section{GEOLOGI DAN MINERALISASI}

Busur vulkanik Pegunungan Barisan berumur Tersier, yang dipengaruhi oleh sesar mendatar berarah baratlauttenggara, dikenal sebagai Zona Sesar Semangko (Pulunggono, 1993, dalam Darman dan Sidi, 2000). Zona sesar ini memberikan pola lineasi struktur di daerah Prospek "X" dan sekitarnya oleh Unit Geomin (2014) yang diinterpretasikan berhubungan dengan zona mineralisasi di daerah penelitian (Gambar 1A, Gambar 1B).

Daerah penelitian menempati batuan vulkanik Formasi Hulusimpang berumur Oligosen Akhir - Miosen Awal yang tersusun oleh breksi vulkanik, konglomerat, batupasir tufan, dan setempat perselingan batupasir dan batulempung lanauan, umumnya terubah. Formasi Hulu Simpang menindih secara tidak selaras Formasi Papanbetupang berumur Oligosen dan Formasi Rawa berumur Kapur-Jura, dan diintrusi oleh Dasit berumur Miosen Tengah (Suwarna dkk., 1992) (Gambar 1C). 
Berdasarkan hasil eksplorasi Unit Geomin (2014), di daerah Prospek "X" terdapat indikasi endapan tipe epitermal sulfida tinggi pada breksi vulkanik sebagai batuan induk. Setempat diintrusi retas andesit dan mikrodiorit, adapun litologi andesit dan dasit terbentuk relatif jauh dari batuan induk. Breksi vulkanik tersusun oleh ubahan argilik lanjut/breksi juvenile, breksi hidrotermal, crackle breccia, dan milled breccia. Ubahan argilik lanjut berkomposisi mineral ubahan vuggymassive quartz, alunit, pirofilit, kaolinit, dan dickit. Pada massive-vuggy quartz dan alunit, terdapat potensi mineralisasi bijih yang teroksidasi sebagian terdiri pirit, enargit, luzonit, kovelit, kalkosit, tenantit, dan tetrahedrit (Gambar 2).

\section{METODOLOGI}

Conto-conto tanah di area seluas berkisar $5,3 \mathrm{~km}^{2}$ diambil pada horison B-C menggunakan hand auger dengan kedalaman sekitar $100 \mathrm{~cm}$ secara kisi 100 $\mathrm{m} \times 50 \mathrm{~m}$, masing-masing conto memiliki titik koordinat (Gambar 3). Kandungan unsur $\mathrm{Au}$ pada conto-conto tersebut dianalisis dengan menggunakan Fire Assay Atomic Absorption Spectrophotometry (FA-AAS), sedangkan unsurunsur $\mathrm{Ag}, \mathrm{Hg}, \mathrm{Te}, \mathrm{Sb}, \mathrm{As}, \mathrm{Bi}, \mathrm{Cu}, \mathrm{Pb}, \mathrm{Zn}$, Sn, dan Mo menggunakan Induced Coupled Plasma Optical Emition Spectrometry (ICP-OES). Unsur-unsur tersebut mengacu pada White dan Hedenquist (1995) dikarenakan hubungannya dengan keterdapatan mineralisasi bijih sulfida.

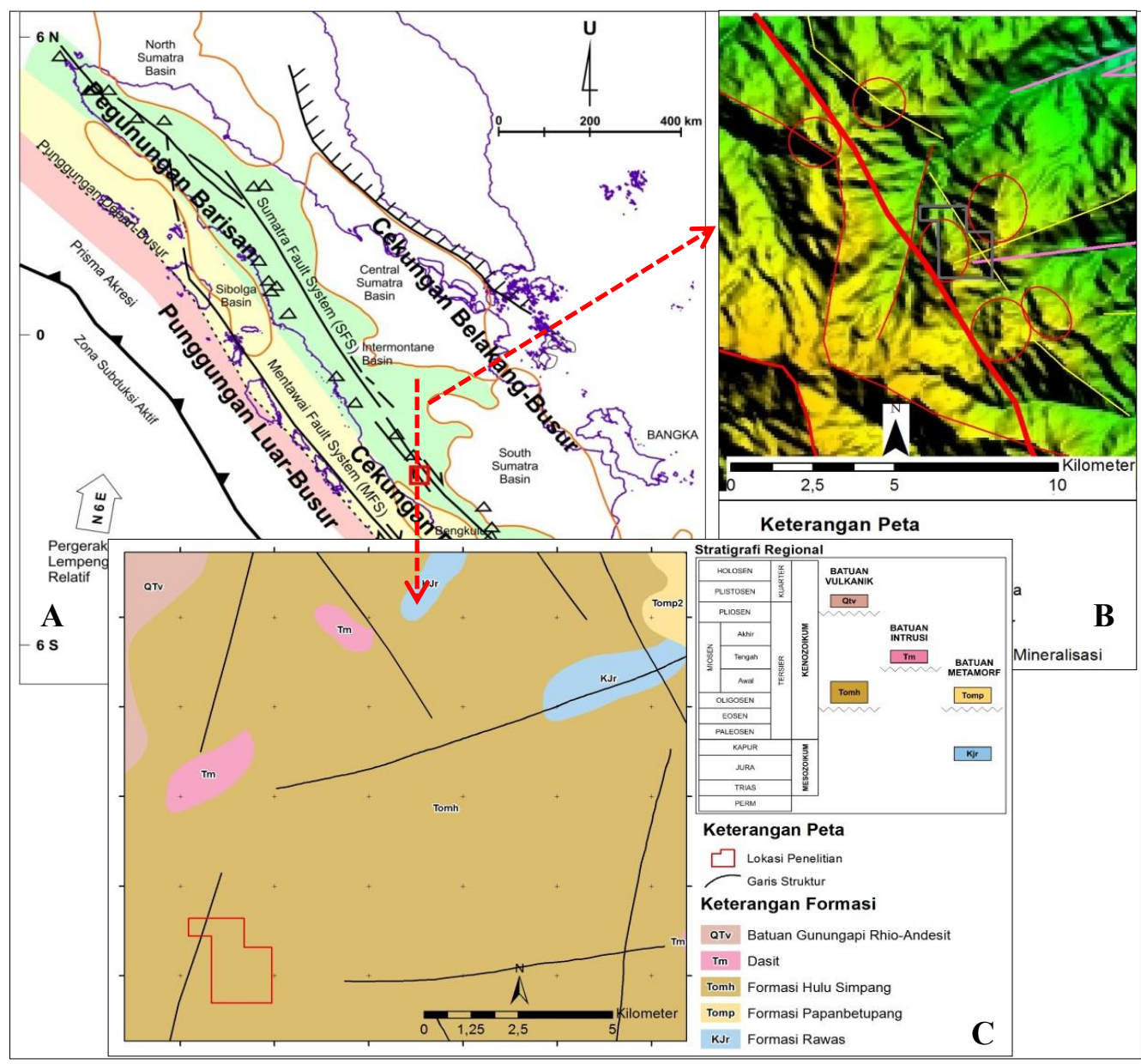

Gambar 1. Peta geologi dan struktur geologi regional daerah lapangan "X", (A) skema kerangka tektonik Pulau Sumatera (Darman and Sidi, 2000); (B) SRTM interpretasi lineasi struktur dan zonasi alterasi-mineralisasi (modifikasi Unit Geomin, 2014); (C) Geologi regional (Suwarna, dkk., 1992). 


\section{MAKALAH ILMIAH}

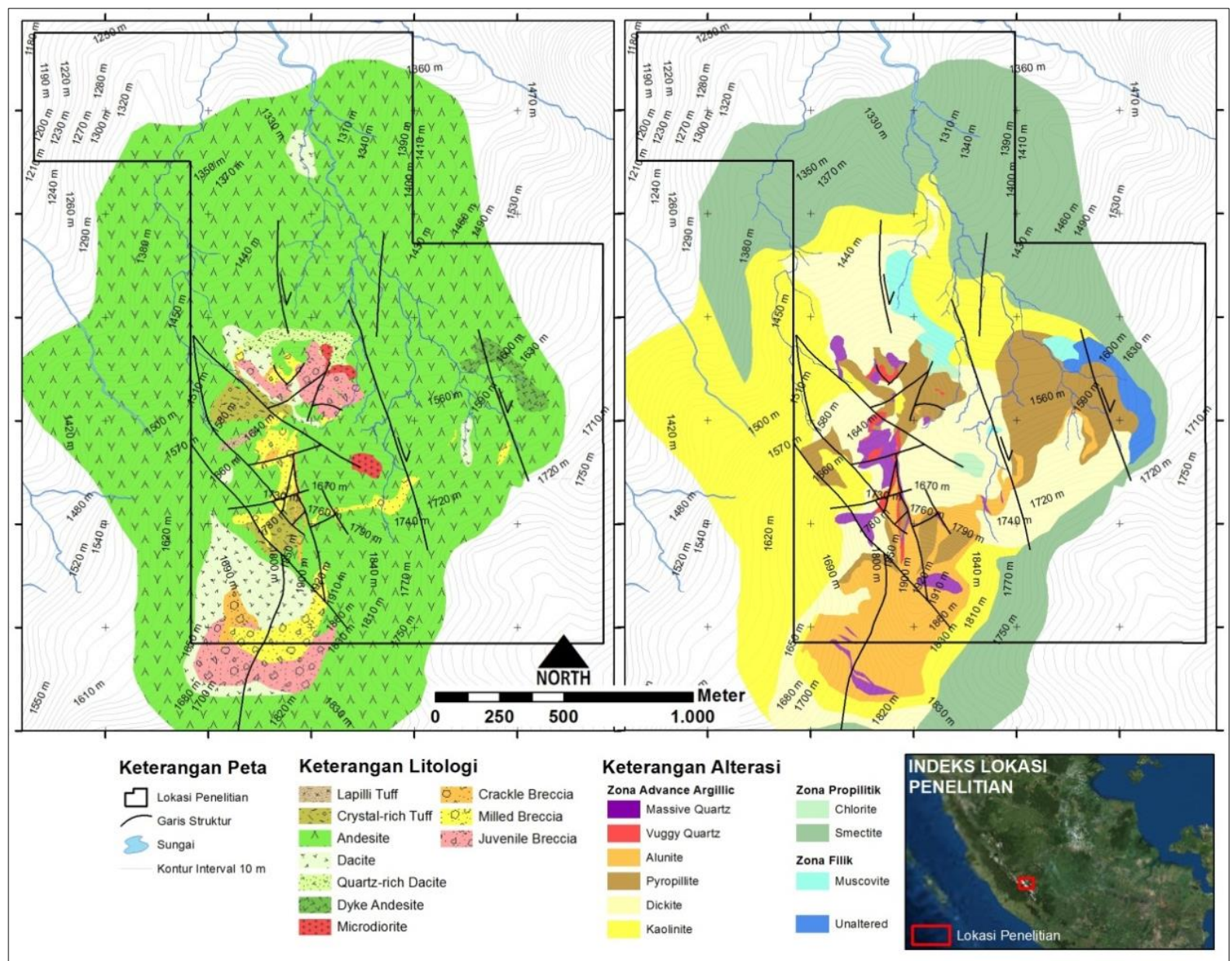

Gambar 2. Peta Geologi dan Alterasi daerah Prospek "X", Batang Asai, Kabupaten Sarolangun, Provinsi Jambi (modifikasi Anonim, 2014).

Metode statistik telah diterapkan secara luas untuk menginterpretasi set data geokimia tanah dan menentukan anomali yang mencerminkan karakteristik geokimia tertentu. Khususnya, integrasi terhadap observasi lapangan, mendeteksi respon mineralisasi, dan menunjang data geologi (Amor, 2011).

Analisis Korelasi dan Analisis Klaster Hirarki diterapkan pada set data geokimia multivariat. Analisis korelasi digunakan untuk menentukan hubungan antara dua variabel dan saling berkaitan satu dengan yang lain. Koefisien korelasi ( $r$ ) merupakan besar kecilnya nilai hubungan antara dua variabel yang dinyatakan dalam jumlah korelasi dengan kisaran nilai $-1 \leq r \leq+1$. Tiap nilai korelasi memiliki tingkatan hubungan (Sugiyono, 1999). Analisis klaster hirarki merupakan salah satu teknik klaster yang telah diterapkan secara luas dalam bidang ilmu kebumian (Davis, 2002). Teknik ini menggunakan metode aglomeratif yang masing-masing objeknya dianggap sebagai klaster terpisah. Dua objek klaster dihubungkan dengan menggunakan metode korelasi Ward. Metode Ward menggunakan nilai kedekatan yaitu korelasi dan atau kovarians untuk mengevaluasi jarak antara klaster dan dapat menghasilkan pengelompokan klaster. Perpaduan antar klaster yang paling mirip kemudian dihubungkan ke objek klaster lain sehingga membentuk semacam "pohon" dimana ada hirarki (tingkatan) antar klaster yang dikenal sebagai Dendrogram (Timm, 2002). 


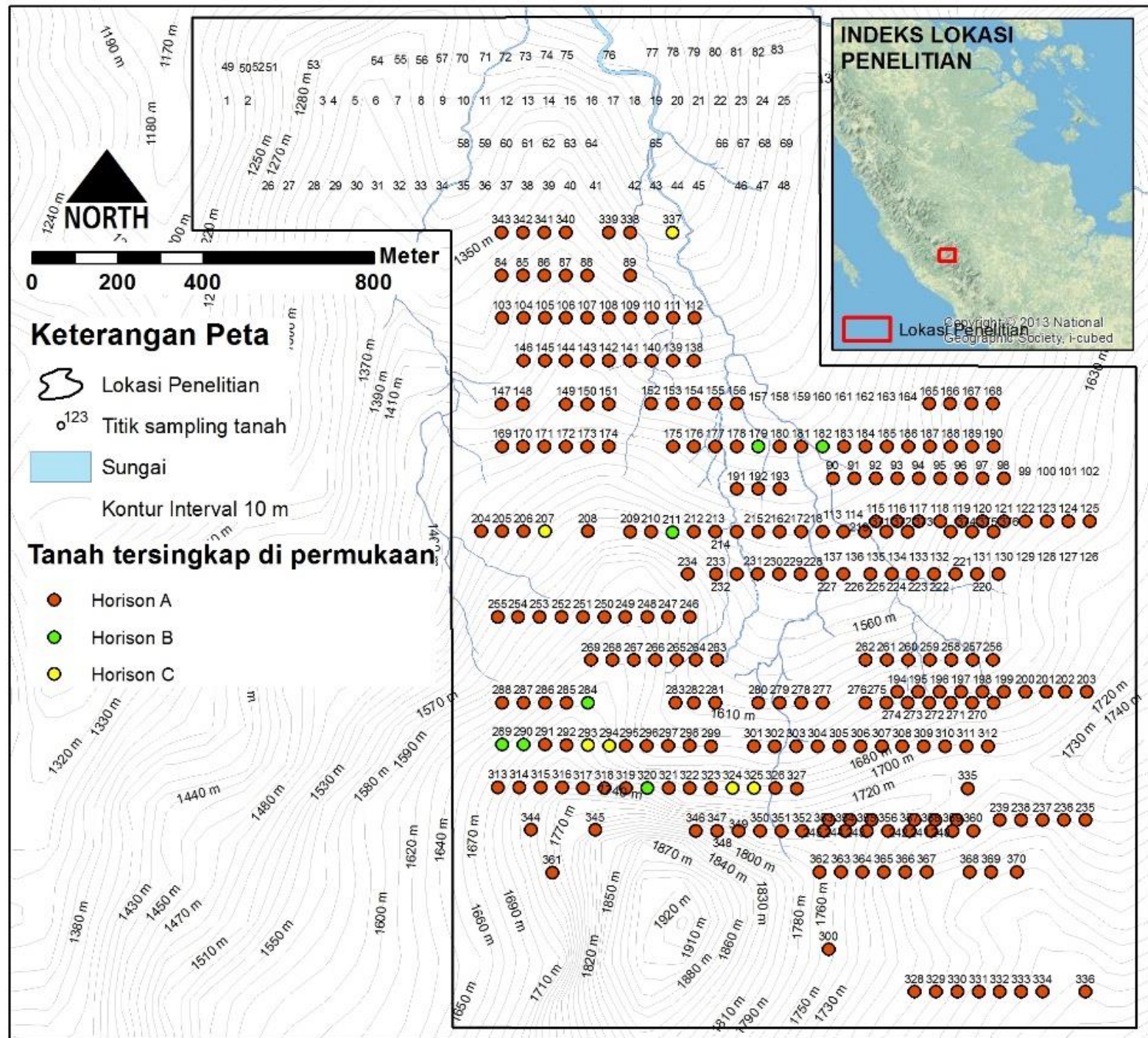

Gambar 3. Lokasi pengambilan conto-conto tanah di daerah Prospek "X".

HASIL

\section{Statistik Deskriptif}

Statistik deskriptif unsur $\mathrm{Au}, \mathrm{Ag}, \mathrm{Hg}, \mathrm{Te}$, $\mathrm{Sb}, \mathrm{As}, \mathrm{Bi}, \mathrm{Cu}, \mathrm{Pb}, \mathrm{Zn}, \mathrm{Sn}$, dan $\mathrm{Mo}$ menunjukkan nilai range, variance, skewness, dan kurtosis relatif tinggi. Khususnya nilai intensitas anomali geokimia tiap unsur umumnya bernilai positif (Tabel 1).

Tabel 1. Statistik deskriptif conto tanah daerah prospek "X".

\begin{tabular}{|c|c|c|c|c|c|c|c|c|c|c|c|c|}
\hline & $\begin{array}{c}A u \\
(p p b)\end{array}$ & $\underset{(\mathbf{p p m})}{\mathrm{Ag}}$ & $\underset{(\mathbf{p p m})}{\mathrm{Hg}}$ & Te (ppm) & $\begin{array}{c}\mathbf{S ~ b} \\
(\mathrm{ppm})\end{array}$ & As (ppm) & $\begin{array}{c}\mathbf{B i} \\
(\mathbf{p p m})\end{array}$ & $\mathrm{Cu}$ (ppb) & $\mathrm{Pb}(\mathrm{ppb})$ & $\mathrm{Zn}(\mathrm{ppb})$ & $\underset{\text { (ppm) }}{\mathbf{S n}}$ & $\begin{array}{c}\text { Mo } \\
\text { (ppm) }\end{array}$ \\
\hline $\begin{array}{l}\text { Jumlah } \\
\text { data }\end{array}$ & 376 & 376 & 376 & 3 & 376 & 6 & 376 & 3 & 376 & 6 & 376 & 376 \\
\hline Kelas & 10 & 10 & 10 & 0 & 10 & 10 & 10 & 10 & 10 & 10 & 10 & 10 \\
\hline Minimum & 0,100 & 1,500 & 2,500 & 1,000 & 2,000 & 0,000 & 1,000 & 1,000 & 0,000 & 1,000 & 0,000 & 1,500 \\
\hline Maximum & 101,000 & 173,910 & 26,090 & 831,700 & 199,410 & 2743,940 & 65,000 & 778,520 & 8513,000 & 926,410 & 68,190 & 61,910 \\
\hline Rentang & 100,900 & 172,410 & 23,590 & 830,700 & 197,410 & 2743,940 & 64,000 & 777,520 & 8513,000 & 925,410 & 68,190 & 60,410 \\
\hline Interval & 10,622 & 18,149 & 2,484 & 87,443 & 20,78 & 288,836 & 6,737 & 81,845 & 896,106 & 97,412 & 7,178 & 6,359 \\
\hline Mean & 6,859 & 6,971 & 3,069 & 7,995 & 7,168 & 53,314 & 3,018 & 19,819 & 86,825 & 52,522 & 8,097 & 3,313 \\
\hline
\end{tabular}




\section{MAKALAH ILMIAH}

\begin{tabular}{|c|c|c|c|c|c|c|c|c|c|c|c|c|}
\hline & $\begin{array}{c}A u \\
(p p b)\end{array}$ & $\underset{(p p m)}{\mathrm{Ag}}$ & $\underset{(\mathrm{ppm})}{\mathrm{Hg}}$ & Te (ppm) & $\begin{array}{c}S \mathbf{b} \\
(\mathrm{ppm})\end{array}$ & As (ppm) & $\begin{array}{c}\mathbf{B i} \\
(\mathbf{p p m})\end{array}$ & $\mathrm{Cu}(\mathrm{ppb})$ & $\mathrm{Pb}(\mathrm{ppb})$ & $\mathrm{Zn}(\mathrm{ppb})$ & $\underset{(p p m)}{S ~ n}$ & $\begin{array}{c}\text { Mo } \\
\text { (ppm) }\end{array}$ \\
\hline $\begin{array}{l}\text { Standar } \\
\text { Dev }\end{array}$ & 13,334 & 18,644 & 2,749 & 43,933 & 15,257 & 147,654 & 6,191 & 46,041 & 443,198 & 65,382 & 10,904 & 4,181 \\
\hline Varians & 177,808 & 347,588 & 7,556 & 1930,113 & 232,784 & 21801,846 & 38,328 & 2119,770 & 196424,829 & 4274,758 & 118,901 & 26,843 \\
\hline Skewness & 4,720 & 5,770 & 5,857 & 17,714 & 6,367 & 16,269 & 5,344 & 12,308 & 18,459 & 7,635 & 2,160 & 6,106 \\
\hline Kurtosis & 27,202 & 39,555 & 37,116 & 331,880 & 67,735 & 295,839 & 39,356 & 197,520 & 351,093 & 90,973 & 4,430 & 53,313 \\
\hline $\begin{array}{l}\text { Anomali } \\
\text { lemah }\end{array}$ & 20,194 & 25,615 & 5,818 & 51,928 & 22,425 & 200,969 & 9,209 & 65,860 & 530,023 & 117,903 & 19,001 & 8,494 \\
\hline $\begin{array}{l}\text { Anomali } \\
\text { sedang }\end{array}$ & 33,528 & 44,258 & 8,567 & 95,861 & 37,682 & 348,623 & 15,400 & 111,901 & 973,222 & 183,285 & 29,906 & 13,676 \\
\hline $\begin{array}{l}\text { Anomali } \\
\text { kuat }\end{array}$ & 362 & 2,902 & 11,316 & 794 & 939 &, 278 & 21,591 & 157,942 & 16,420 & 8,667 & 810 & 8,857 \\
\hline
\end{tabular}

\section{Histogram dan Box-whisker plots}

Histogram yang dihasilkan oleh tiap unsur berdasarkan kelas interval dan frekuensi kumulatif mengidentifikasi kecondongan/skewness digunakan untuk distribusi dan kelengkungan/kurtosis suatu data. Box- whisker plot mengidentifikasi distribusi box berupa bidang Interquartile Range (IQR), median, garis whisker, outlier, dan ekstrim suatu data. Dilakukan penentuan antara nilai background dan intensitas anomali terdiri dari anomali lemah (mean + 1SD), sedang (mean $+2 \mathrm{SD}$ ), hingga kuat (mean + 3SD) pada diagram ini (Gambar 4).

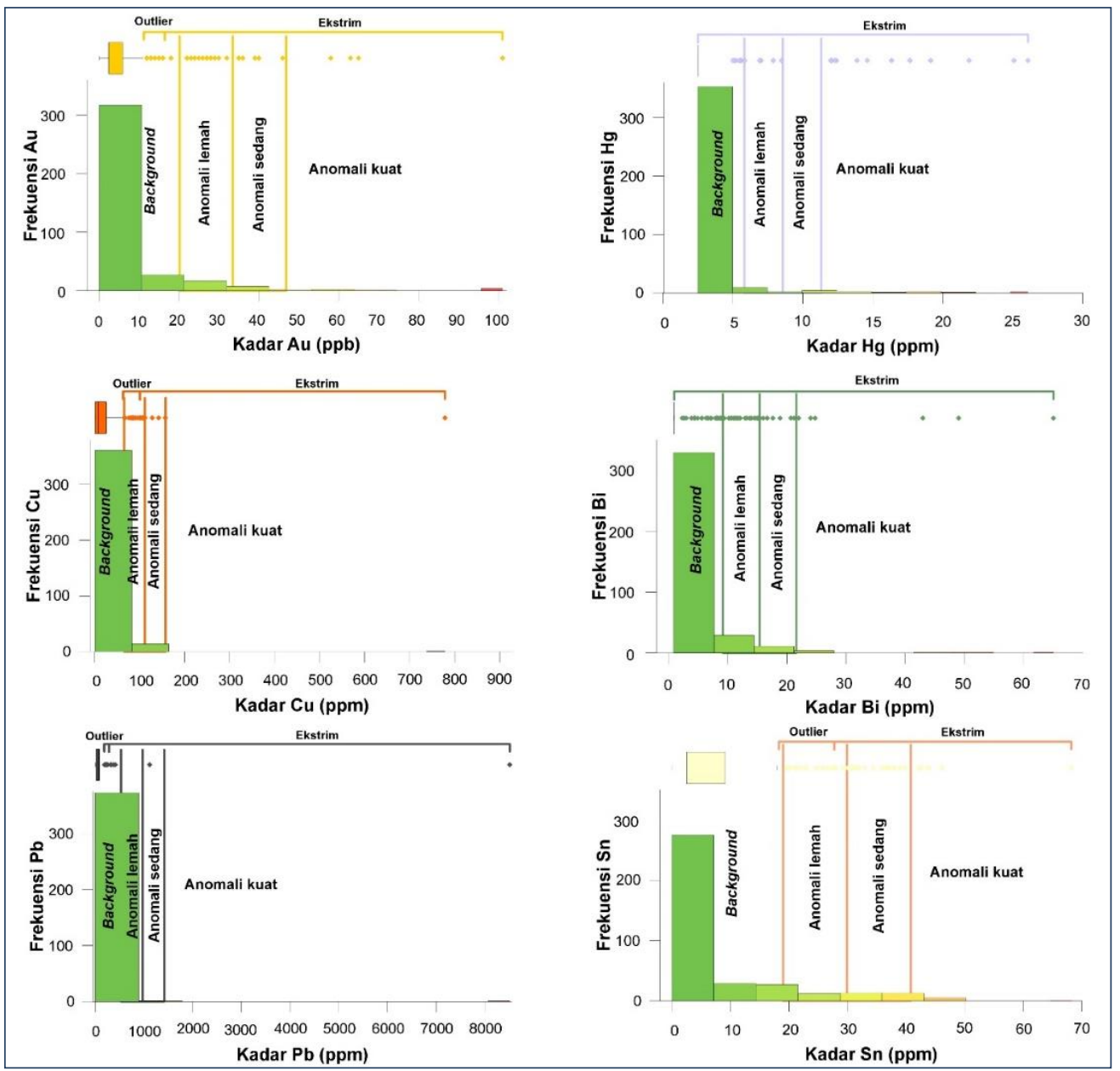

Gambar 4. Histogram dan box-whisker plots unsur $\mathrm{Au}, \mathrm{Hg}, \mathrm{Cu}, \mathrm{Bi}, \mathrm{Pb}$, dan $\mathrm{Sn}$ di daerah prospek "X". 
Histogram dan box-whisker plots yang direpresentasikan oleh beberapa unsur tersebut di atas menunjukkan bahwa data umumnya terdistribusi tidak normal. Histogram umumnya condong ke arah kanan, nilai kecondongan bersifat positif memberikan nilai anomali positif dengan intensitas anomali bervariasi. Box-whisker plots didapat variabel unsur-unsur yang memiliki nilai IQR dan tidak memiliki IQR. Unsur $\mathrm{Au}, \mathrm{Ag}, \mathrm{Te}, \mathrm{Cu}, \mathrm{Pb}, \mathrm{Zn}$, dan $\mathrm{Sn}$ memiliki nilai IQR dan whisker sehingga teridentifikasi outlier pada $>1.5 \times \mathrm{IQR}$, disertai nilai ekstrim pada $>3.0 \times$ IQR. Unsur $\mathrm{Hg}, \mathrm{Sb}, \mathrm{Bi}$, dan Mo tidak memiliki nilai IQR dan whisker sehingga hanya didapat nilai ekstrim.

\section{Analisis Korelasi}

Analisis korelasi dilakukan untuk melihat kaitannya dengan tingkat hubungan nilai koefisien korelasi. Jumlah individu koefisien korelasi tersebut adalah sebanyak 132 individu. Range nilai koefisien korelasi semua individu tersebut dibagi menjadi dua, yaitu range korelasi negatif $(-)$ berkisar -0.006 s/d. $\quad-0.109$ memiliki tingkat hubungan sangat rendah, dan range korelasi positif $(+)$ berkisar $0.002 \mathrm{~s} / \mathrm{d} 0.928$ memiliki tingkat hubungan sangat rendah hingga sangat kuat (Gambar 5A). Range nilai koefisien korelasi dibatasi mulai dari tingkat hubungan rendah yaitu pada nilai korelasi $0.2 \mathrm{~s} / \mathrm{d} 1.0$ agar analisis korelasi unsur bersifat representatif untuk dilakukan (Gambar 5B). Berdasarkan diagram tersebut, terdapat korelasi unsur $\mathrm{Au}, \mathrm{Hg}$, $\mathrm{Te}, \mathrm{Sb}, \mathrm{As}, \mathrm{Bi}, \mathrm{Cu}$, dan $\mathrm{Sn}$ bersifat representatif dicirikan nilai koefisien korelasi $>0,2$, sedangkan $\mathrm{Ag}, \mathrm{Pb}, \mathrm{Zn}$, dan Mo bersifat tidak representatif dicirikan nilai koefisien korelasi <0,2.

\section{Analisis Klaster Hirarki}

Dendrogram yang dihasilkan oleh klaster hirarki dengan menggunakan metode korelasi Ward dikelompokkan menjadi empat klaster. Klaster I terbentuk pada jarak perhubungan 0,53 dan nilai kemiripan 73,60, menghasilkan kekerabatan unsur $\mathrm{Cu}$, $\mathrm{As}, \mathrm{Sb}$, dan $\mathrm{Te}$. Klaster II terbentuk pada jarak perhubungan 0,74 dan nilai kemiripan 62,98, menghasilkan ke-kerabatan unsur $\mathrm{Au}$ dan $\mathrm{Bi}$. Klaster III terbentuk pada jarak perhubungan 0,91 dan nilai kemiripan 54,38, menghasilkan kekerabatan unsur $\mathrm{Pb}$, Mo, dan $\mathrm{Zn}$. Klaster IV terbentuk pada jarak perhubungan 1,02 dan nilai kemiripan 49,01, menghasilkan kekerabatan unsur $\mathrm{Sn}, \mathrm{Hg}$, dan $\mathrm{Ag}$ (Tabel 2).

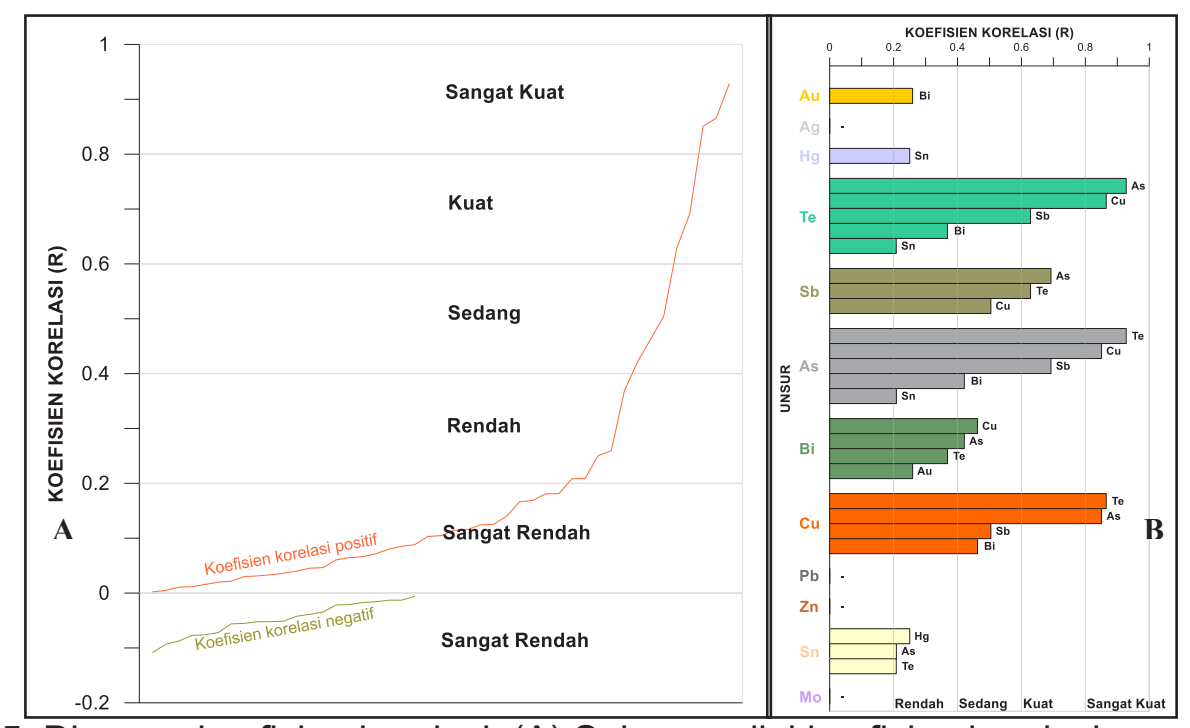

Gambar 5. Diagram koefisien korelasi, (A) Sebaran nilai koefisien korelasi secara berurut menggambarkan tingkat hubungan; (B) Koefisien korelasi unsur-unsur saling berkaitan satu dengan yang lain pada tingkat hubungan 02.-1.0. 


\section{MAKALAH ILMIAH}

Tabel 2. Nilai-nilai jarak, kemiripan, dan koefisien korelasi pada tiap klaster.

\begin{tabular}{|c|c|c|c|c|c|c|c|c|}
\hline Klaster & I & & & & I & & & \\
\hline Unsur & Cu-As- & $\mathrm{b}-\mathrm{Te}$ & & & $\mathrm{Pb}-\mathrm{N}$ & $-Z n$ & Sn-H & $-\mathrm{Ag}$ \\
\hline Nilai kemiripan & 73,6 & & & 79 & 54,3 & & 49 & \\
\hline Nilai jarak & 0,5 & & & 40 & $0, \mathrm{c}$ & & & \\
\hline $\begin{array}{l}\text { Range koefisien } \\
\text { korelasi }\end{array}$ & $0,504-$ & 927 & & & 0,085 & , 115 & 0,016 &, 251 \\
\hline & & ster re & esenta & & Kla & er tidak & presen & \\
\hline & As-Te & 0,927 & $\mathrm{Au}-\mathrm{Bi}$ & 0,259 & $\mathrm{~Pb}-\mathrm{Zn}$ & 0,103 & $\mathrm{Sn}-\mathrm{Hg}$ & 0,251 \\
\hline & Cu-Te & 0,865 & & & Mo-Pb & 0,115 & $\mathrm{Ag}-\mathrm{Sn}$ & 0,080 \\
\hline Koefisien & As-Cu & 0,851 & & & Zn-Mo & 0,085 & $\mathrm{Hg}-\mathrm{Ag}$ & 0,016 \\
\hline korelasi (r) & Sb-As & 0,693 & & & & & & \\
\hline & Te-Sb & 0,629 & & & & & & \\
\hline & Cu-Sb & 0,504 & & & & & & \\
\hline
\end{tabular}

Berdasarkan identifikasi pengelompokan klaster di atas, unsur $\mathrm{Cu}, \mathrm{As}, \mathrm{Sb}$, dan $\mathrm{Te}$ memiliki kekerabatan dengan nilai kemiripan relatif tinggi. Nilai kemiripan tinggi mengindikasikan bahwa kekerabatan antar unsur relatif kuat. Secara berurut diikuti pula oleh kekerabatan unsur $\mathrm{Au}$ dan $\mathrm{Bi} ; \mathrm{Pb}$, Mo, dan $\mathrm{Zn}$; serta $\mathrm{Sn}, \mathrm{Hg}$, dan Ag.

Hasil analisis korelasi dan analisis klaster hirarki pada tabel tersebut di atas dapat dicocokkan. Hal tersebut dilakukan agar kekerabatan suatu unsur dapat dibuktikan oleh bagaimana sebaran nilai koefisien korelasi pada tiap klaster tersebut.

Kombinasi dari kedua analisis tersebut menghasilkan klaster yang bersifat representatif terdiri dari Klaster I dan II, serta tidak representatif terdiri dari Klaster III dan IV (Tabel 2).

\section{PEMBAHASAN}

\section{Zona Anomali Geokimia Unsur Tunggal}

Zona anomali geokimia unsur tunggal berupa penentuan zona anomali berdasarkan intensitas anomali unsur yang telah dikalkulasi secara statistik. Masing-masing unsur menunjukkan zona anomali tidak merata dan terdapat pada posisi tertentu (Gambar 6).

Peta zona anomali tiap unsur yang direpresentasikan oleh beberapa unsur tersebut di atas menunjukkan intensitas anomali mulai dari yang lemah hingga kuat. Unsur-unsur dengan sebaran anomali $\geq 200 \mathrm{~m}$, terdiri $\mathrm{Au}, \mathrm{Ag}$, Mo, Sb, dan As. Unsur-unsur dengan sebaran anomali $\leq 200 \mathrm{~m}$, terdiri $\mathrm{Hg}, \mathrm{Cu}, \mathrm{Zn}, \mathrm{Te}, \mathrm{Bi}$ $\mathrm{Pb}$, dan $\mathrm{Sn}$. 


\section{MAKALAH ILMIAH}
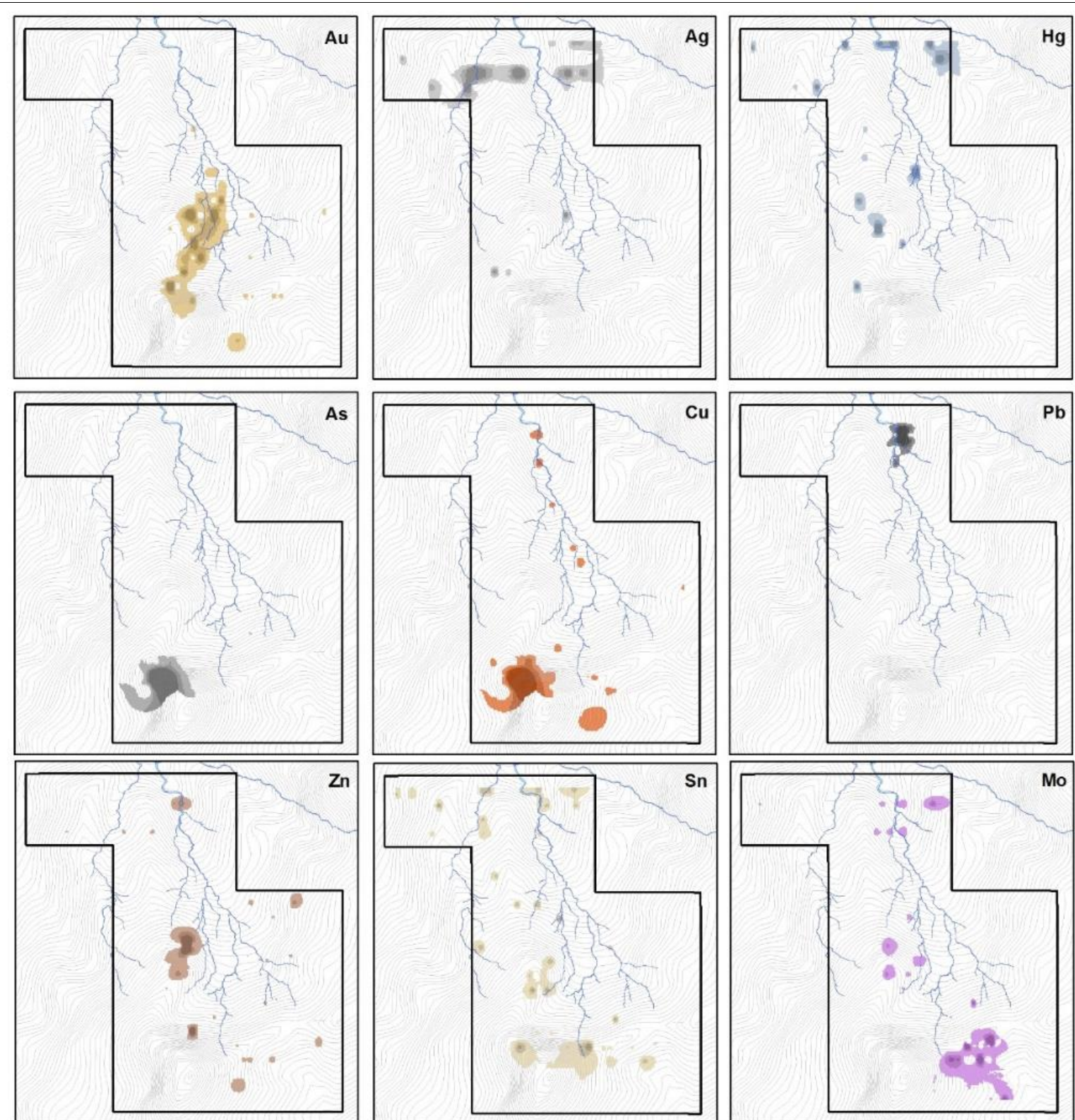

Keterangan Peta

Lokasi Penelitian

Sungai

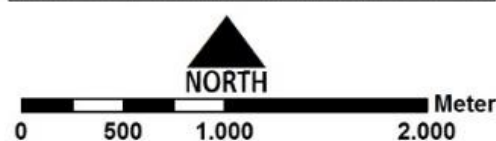

Kontur Interval $10 \mathrm{~m}$

Gambar 6. Peta zona anomali tiap unsur geokimia tanah $\mathrm{Au}, \mathrm{Ag}, \mathrm{Hg}, \mathrm{As}, \mathrm{Cu}, \mathrm{Pb}, \mathrm{Zn}, \mathrm{Sn}$, dan Mo.

\section{Zona Anomali Geokimia Multi Unsur}

Dalam penentuan zona anomali geokimia unsur, telah dijelaskan bahwa analisis statistik multivariat didapat empat klaster yang mana tiap klaster mencerminkan karakteristik kekerabatan antar unsur (Gambar 7). Pemodelan zona anomali ini berupa interpretasi zona anomali geokimia tanah berdasarkan klaster yang mencirikan kekerabatan antar unsur. Interpretasi zona anomali klaster yaitu dengan cara overlay terhadap unsur-unsur yang telah di-kelompokkan oleh tiap klaster. 


\section{MAKALAH ILMIAH}

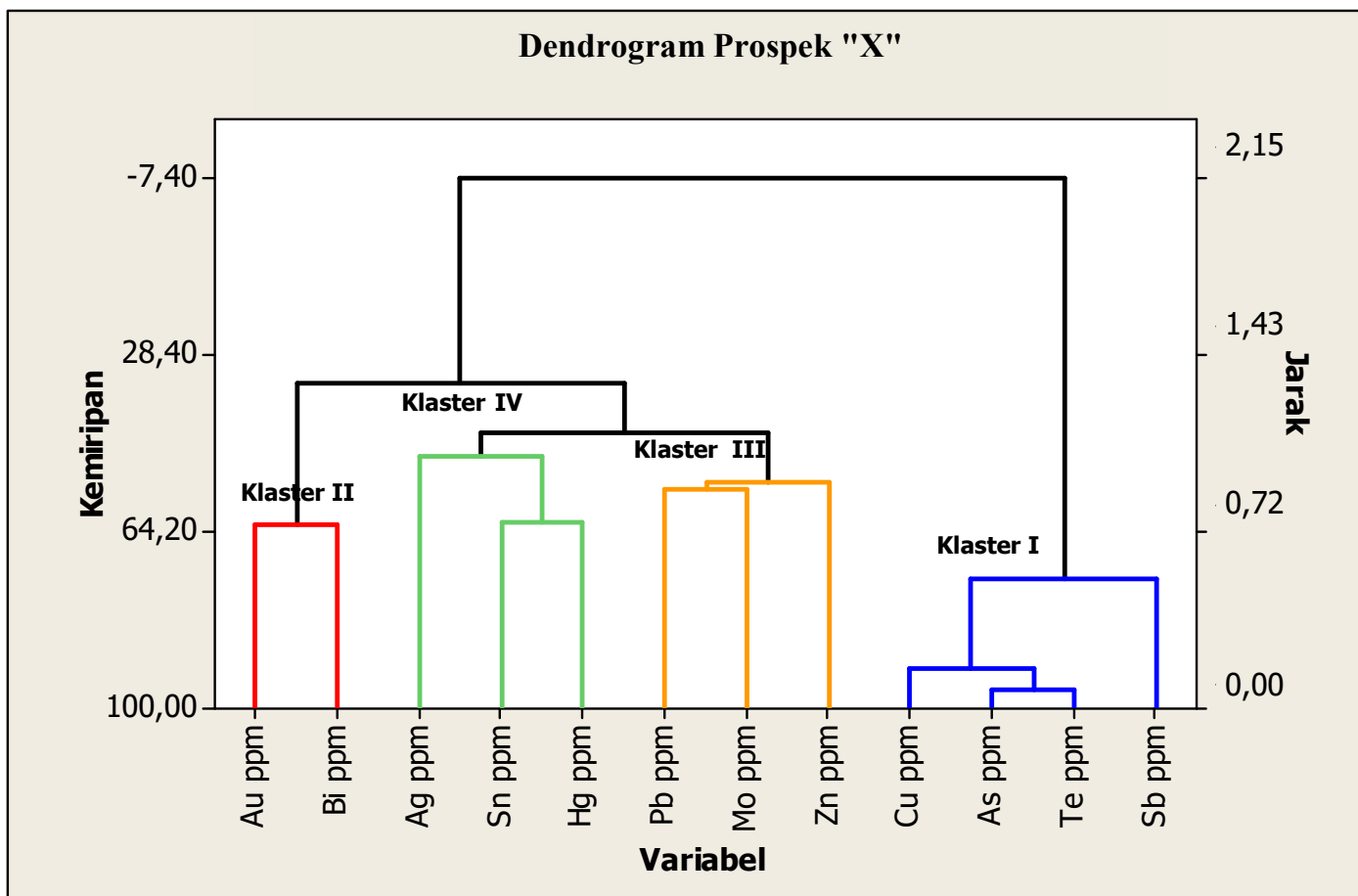

Gambar 7. Dendrogram prospek "X" menunjukkan hirarki pengelompokan kekerabatan unsur yang terbagi menjadi empat klaster.

Klaster yang bersifat representatif terdiri dari Klaster I Cu-As-Sb-Te dan Klaster II $\mathrm{Au}-\mathrm{Bi}$. Zona anomali Klaster I untuk tiap unsurnya cenderung berkumpul dan saling tumpang tindih di satu tempat yaitu pada bagian baratdaya lokasi penelitian (Gambar 8A). Zona anomali Klaster II untuk tiap unsurnya cenderung saling tumpang tindih di empat tempat, namum sebagian besar hanya terdapat di satu tempat yaitu pada bagian baratdaya lokasi penelitian (Gambar 8B).
Klaster yang bersifat tidak representatif terdiri dari Klaster III Pb-Mo-Zn dan Klaster IV Sn-Hg-Ag. Zona anomali Klaster III untuk tiap unsurnya cenderung saling tumpang tindih di satu tempat yaitu pada bagian utara lokasi penelitian (Gambar 9A). Begitu pula dengan zona anomali Klaster IV, umumnya terdapat pada bagian utara lokasi penelitian (Gambar 9B).

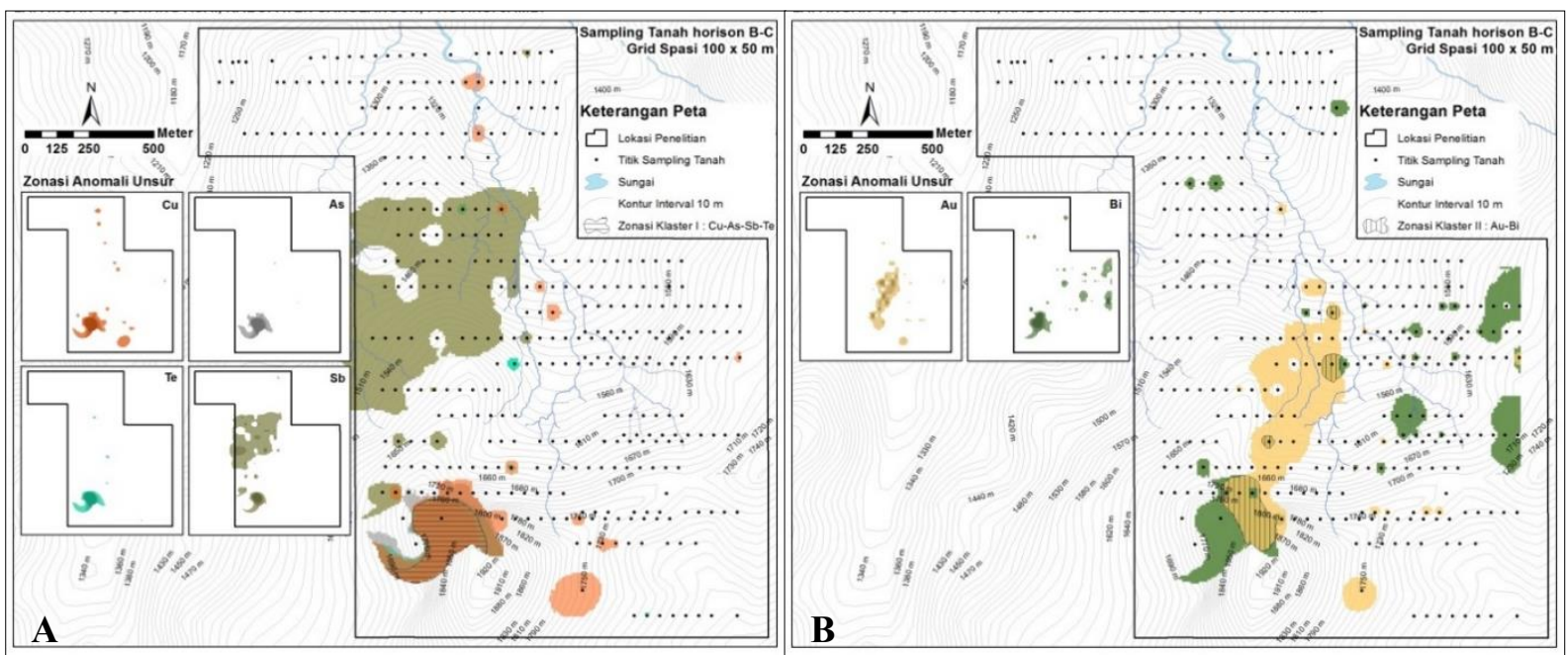

Gambar 8. Peta zona anomali klaster, (A) Klaster I Cu-As-Sb-Te; (B) Klaster II Au-Bi. 


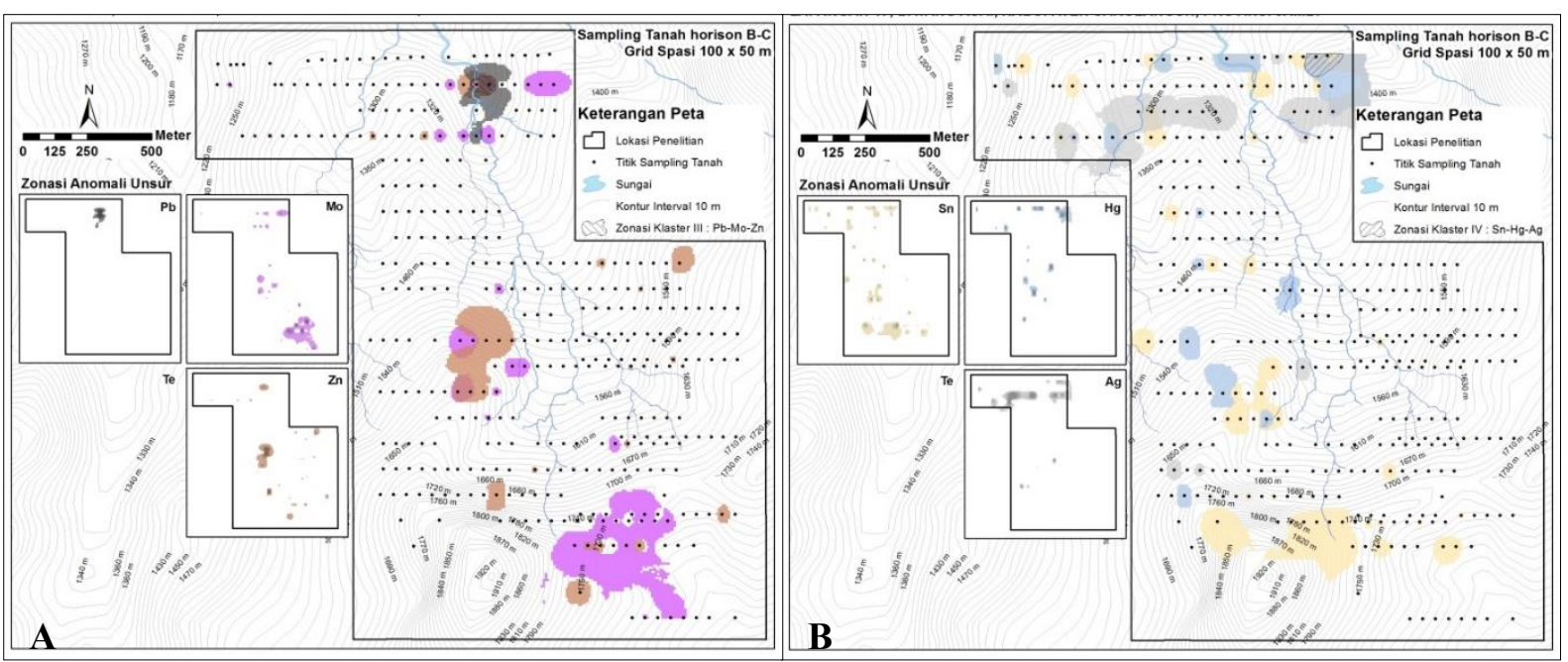

Gambar 9. Peta zona anomali klaster, (A) Klaster III Pb-Mo-Zn; (B) Klaster IV Sn-Hg-Ag.

\section{Interpretasi Anomali Geokimia, Litologi, Alterasi, dan Mineralisasi}

Zonasi anomali klaster tersebut mencirikan kekerabatan antar unsur yang menghasilkan dua variabel klaster yaitu klaster yang bersifat representatif dan klaster yang bersifat tidak representatif. Dua variabel tersebut akan diinterpretasi hubungannya terhadap litologi, alterasi, dan mineralisasi di permukaan.

Distribusi zona anomali unsur Cu-As-Sb$\mathrm{Te}$ dan $\mathrm{Au}-\mathrm{Bi}$ merupakan zona yang dikategorikan representatif untuk dapat dilakukan interpretasi. Interpretasi yang mengacu pada kumpulan asosiasi unsur tersebut, berkaitan dengan keterdapatan mineralisasi sulfida. Mineralisasi tersebut mencerminkan karakteristik litologi dan alterasi. Kedua zona tersebut memiliki zona anomali yang saling beririsan satu sama lain. Kedua zona anomali kumpulan unsur ini menempati litologi crystal-rich tuff, andesit, dasit, crackle breccia, dan milled breccia. Disertai pula dengan alterasi pada zona anomali tersebut menempati ubahan argilik lanjut yang tersusun oleh kuarsa vughs, kuarsa masif, alunit, pirofilit, dan dickit (Gambar 10A).

Zona anomali unsur Cu-As-Sb-Te berdasarkan deskripsi petrografi dan mineragrafi diwakili oleh conto inti bor yang terdapat pada zona tersebut yaitu GS-DH07 dan GS-DH08. Conto-conto tersebut berkomposisi mineral sulfida terdiri dari enargit $\mathrm{Cu}_{3}(\mathrm{As}, \mathrm{Sb}) \mathrm{S}_{4}$, luzonit $\mathrm{Cu}_{3}(\mathrm{As}, \mathrm{Sb}) \mathrm{S}_{4}$, kovelit CuS, kalkopirit $\mathrm{CuFeS}_{2}$, dan arsenopirit FeAsS pada batuan terubah silisifikasi berkomposisi mikrogranular silika dan alunit (Gambar 11). Tetapi, untuk zona anomali unsur AuBi tidak dijumpai indikasi mineralisasi yang mewakili kumpulan unsur tersebut.

Distribusi zona anomali unsur $\mathrm{Pb}-\mathrm{Mo}-\mathrm{Zn}$ dan $\mathrm{Sn}-\mathrm{Hg}-\mathrm{Ag}$ merupakan zona yang dikategorikan tidak representatif untuk dapat dilakukan interpretasi. Hal tersebut dikarenakan kedua kumpulan unsur tersebut menempati litologi dan alterasi yang tidak representatif pula. Zona anomali unsur $\mathrm{Pb}-\mathrm{Mo}-\mathrm{Zn}$ dan $\mathrm{Sn}-\mathrm{Hg}-\mathrm{Ag}$ menempati litologi andesit terubah smektit (Gambar 10B). 


\section{MAKALAH ILMIAH}

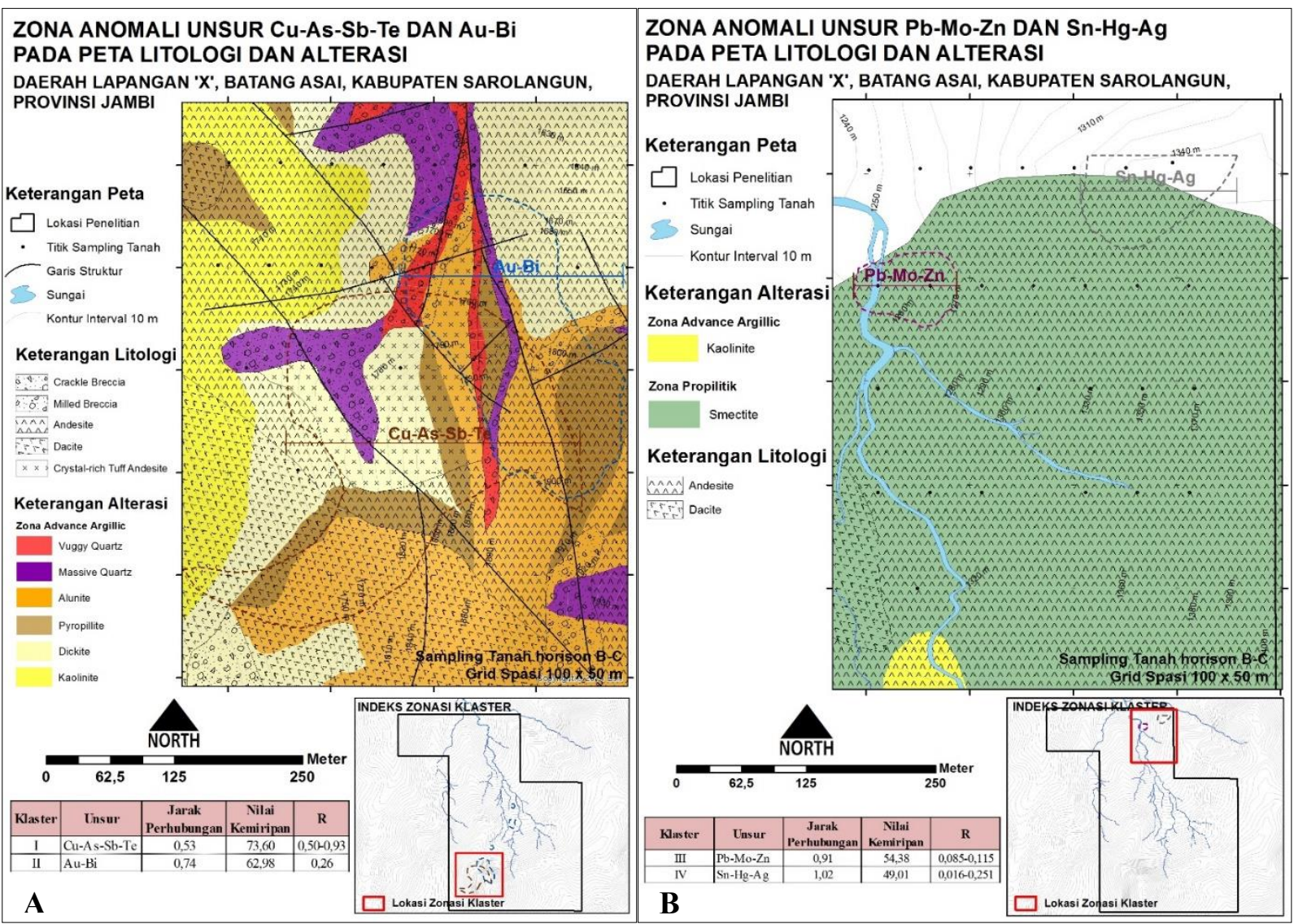

Gambar 10. Zona anomali unsur Cu-As-Sb-Te dan Au-Bi pada peta litologi dan alterasi.

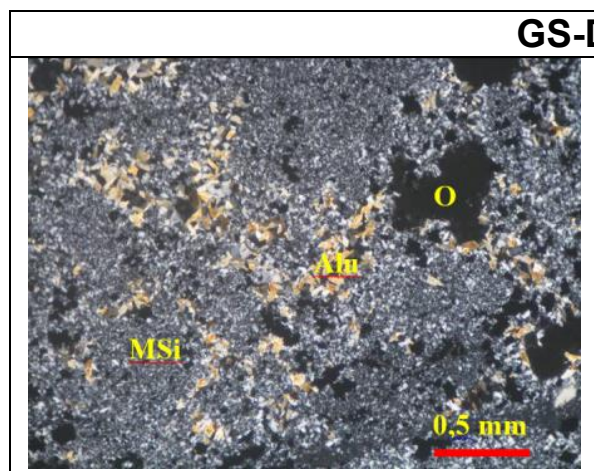

(a) X-Nikol

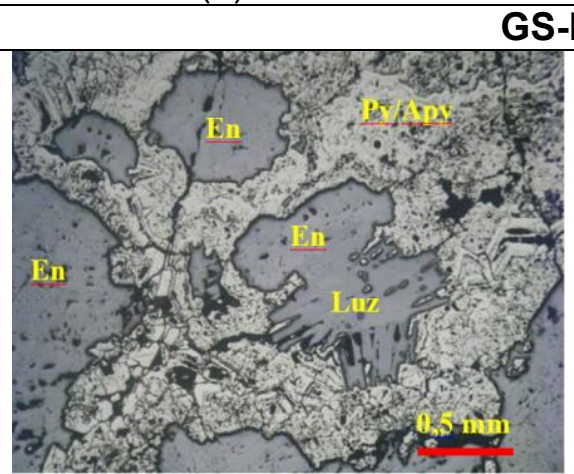

(c) //-Nikol

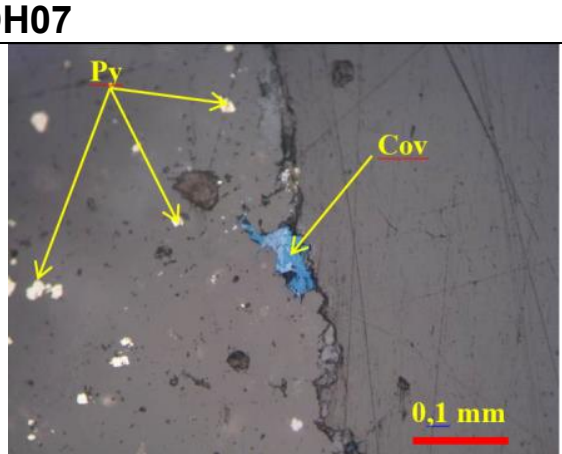

(b) //-Nikol

GS-DH08

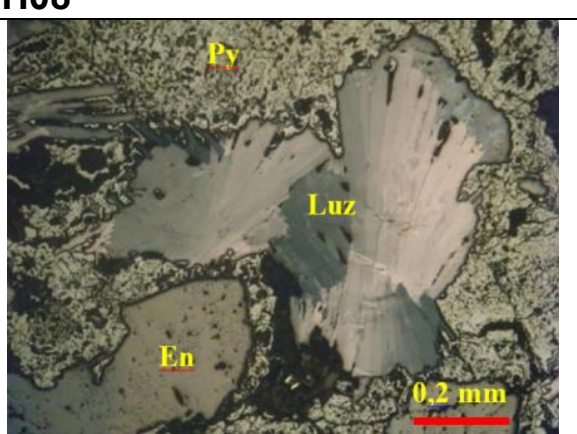

(d) X-Nikol

Gambar 11. Fotomikrograf sayatan tipis dan fotomikrograf sayatan poles conto GS-DH07 dan GS-DH08. 


\section{KESIMPULAN}

Hasil analisis statistik univariat mengindikasikan zona anomali geokimia tiap unsur yang berkaitan dengan zona anomali berdasarkan kalkulasi statistik deskriptif, histogram, dan box-whisker plots sehingga dapat diidentifikasi nilai background dan intensitas anomali. Hasil analisis statistik multivariat mengindikasikan interpretasi zona anomali geokimia klaster yang bersifat representatif dan tidak representatif. Klaster yang bersifat representatif terdiri Klaster I Cu-As-Sb-Te dan Klaster II Au-Bi, sedangkan klaster yang bersifat tidak representatif terdiri Klaster III $\mathrm{Pb}-\mathrm{Mo}-\mathrm{Zn}$ dan Klaster IV Sn-Hg-Ag. Kumpulan asosiasi unsur geokimia tanah $\mathrm{Cu}-\mathrm{As}-\mathrm{Sb}-$ $\mathrm{Te}$ dan $\mathrm{Au}-\mathrm{Bi}$ merupakan unsur-unsur signifikan yang mengindikasikan anomali permukaan. Anomali ini diterapkan untuk meng-interpretasi keberadaan potensi mineralisasi $\mathrm{Au}-\mathrm{Cu}$ epitermal sulfida tinggi yang tersusun oleh ubahan argilik lanjut dari breksi vulkanik, tuf, andesit, dan dasit; serta dicirikan oleh kehadiran mineral bijih enargit, luzonit, kalkopirit, arsenopirit, dan kovelit. Adapun sebagian hasil analisis geokimia tanah khususnya unsur Te dan Bi tidak menunjukkan kaitannya dengan mineralisasi $\mathrm{Au}-\mathrm{Cu}$. Hal tersebut diinterpretasikan bahwa keberadaan unsur $\mathrm{Te}$ dan $\mathrm{Bi}$ dapat berupa ion yang mengisi kisi kristal pada zona mineralisasi $\mathrm{Au}-\mathrm{Cu}$ tersebut. Sedangkan kumpulan asosiasi unsur geokimia tanah $\mathrm{Pb}-\mathrm{Mo}-\mathrm{Zn}$ dan $\mathrm{Sn}-$ $\mathrm{Hg}$-Ag merupakan unsur-unsur nonsignifikan dalam kaitannya dengan keberadaan potensi mineralisasi $\mathrm{Au}-\mathrm{Cu}$.

\section{UCAPAN TERIMA KASIH}

Penelitian ini didukung oleh PT ANTAM Tbk Unit Geomin. Dalam kesempatan ini, penulis ingin meng-ucapkan terima kasih kepada Bapak Eko Martias sebagai General Manager, Bapak Hartono sebagai Vice President, dan Bapak Bronto Sutopo sebagai pembimbing teknis, karena diberikan izin untuk mengumpulkan data dan mempublikasikannya.

\section{DAFTAR PUSTAKA}

Amor, S., 2011, Data Presentation and Interpretation Requirements for Geochemical Exploration, Consultant, Burlington.

Darman, H., and Sidi, F.H., 2000, An Outline of The Geology of Indonesia, Ikatan Ahli Geologi Indonesia, Jakarta.

Davis, J.C., 2002, Statistics and Data Analysis in Geology : Third Edition, Kansas Geological Survey, The University of Kansan, John Wiley \& Sons, Inc., New York, 656 p.

Joyce, A.S., 1984, Geochemical Exploration, The Australian Mineral Foundation Inc., Brisbane.

McQueen, K.G., 2002, Identifying Geochemical Anomalies, CRC LEME, Department of Earth and Marine Sciences, Australian National University, Canberra.

Niton, 2012, Application of the Thermo Scientific Portable XRF Analyzer in $P G E$ Exploration, Thermo Fisher Scientific Inc., USA.

Sugiyono, 1999, Statistika Untuk Penelitian, CV. Alfabeta, Bandung.

Suwarna, N., Soeharsono, Gafoer, S., Amin. T.C., Kusnama, dan Hermanto., B, 1992, Peta Geologi Lembar Sarolangun, Sumatera, Skala 1 : 250.000, Pusat Penelitian dan Pengembangan Geologi, Bandung.

Timm, N.H., 2002, Applied Multivariate Analysis, Library of Congress Cataloging-in-Publication Data, Springer-Verlag New York, Inc., New York.

Anonim, 2014, Laporan Akhir Eksplorasi Emas dan Mineral Pengikutnya, daerah Batangasai, Kabupaten Sarolangun, Provinsi Jambi, PT ANTAM Tbk Unit Geomin, Jakarta. Tidak dipublikasikan. 


\section{MAKALAH ILMIAH}

White, N.C., and Hedenquist, J.W., 1995,

Society of Economic Geologists Epithermal Gold Deposits: Styles, Characteristics, and Exploration, Newsletter No. 23, p. 9-13.

$\begin{array}{ll}\text { Diterima } & : 3 \text { Maret } 2016 \\ \text { Direvisi } & : 28 \text { April } 2016 \\ \text { Disetujui } & : 23 \text { Mei } 2016\end{array}$

